\title{
HUBUNGAN SISTEM KOMPUTERISASI DENGAN KEPUASAN MAHASISWA DI POLITEKNIK KESEHATAN JAKARTA II JURUSAN TEKNIK ELEKTROMEDIK
}

\author{
AMANUDIN \\ Dosen Pendidikan Ekonomi, Universitas Pamulang \\ dosen01795@unpam.ac.id.
}

\begin{abstract}
ABSTRAK
Tujuan Penelitian ini untuk memberikan masukan kepada semua komunitas atau kelompok kerja pegawai atau karyawan dalam meningkatkan kualitas pelayanan terhadap mahasiswa, untuk mengetahui sejauh mana hubungan sistem komputerisasi yaitu dalam mengoptimalkan penggunaan dalam rangka memberikan kepuasan pelayanan terhadap mahasiswa, untuk mengetahui upaya lembaga dalam rangka mengatasi hambatan-hambatan yang ada didalam memberikan pelayanan yang terhadap mahasiswa. Suatu pekerjaan pada dasarnya memerlukan kecepatan dalam prosesnya dan ketepatan dalam penyampaian hasilnya serta berusaha meng-efisienkan dari segi pendanaan dan tenaga. Sedangkan jenis pekerjaan yang ada dapat berbentuk pekerjaan yang sama dan rutin dari waktu ke waktu tetapi ada juga jenis pekerjaan yang tidak dan tidak rutin. Salah satu usaha yang harus dilakukan oleh suatu institusi pendidikan dalam melakukan pekerjaan yang sifatnya rutinitas dan formatnya selalu sama seperti pendataan mahasiswa baru, membuat absen perkuliahan, absen ujian, format kartu rencana studi, kartu hasil studi dan lain sebagainya, maka perlu sekali menggunakan alat bantu kerja berupa komputer, namun dengan komputer saja tidaklah cukup karena komputer tidak dapat bekerja tanpa adanya program khusus yang berkaitan dengan pekerjaan yang diharapkan. Untuk itu diperlukan jasa seorang programer untuk melakukan hal tersebut. Sebuah institusi pendidikan yang sudah maju dengan jumlah mahasiswa yang cukup banyak sekiranya perlu menerapkan sistem komputerisasi, sebab dengan sistem komputerisasi yang baik, maka akan dapat meningkatkan hasil pekerjaan, mutu pekerjaan dalam waktu yang relatif singkat, sehingga akan dapat meningkatkan mutu pelayanan kepada konsumennya. Konsumen akan merasa puas bila apa yang diharapkan akan tercapai, dan konsumen akan lebih puas bila hasil yang dirasakan melebihi apa yang diharapkannya.Hipotesis penelitian dapat dirumuskan sebagai berikut: Diduga terdapat hubungan yang positif antara sistem komputerisasi dengan kepuasan mahasiswa di Politeknik Kesehatan Jakarta II Jurusan Teknik Elektromedik.
\end{abstract}

Kata Kunci: Komputerisasi dan Kepuasan 


\section{PENDAHULUAN}

Sejalan dengan meningkatnya perkembangan dalam bidang Ilmu Pengetahuan dan Teknologi (IPTEK) dewasa ini, khususnya teknologi di bidang informasi dan komputer, maka kebutuhan akan informasi dan komputer juga semakin meningkat. Komputer bagi suatu lembaga sangatlah penting, karena pemakai informasi selalu menghendaki sejumlah informasi yang cepat dan akurat. Lembaga Politeknik Kesehatan Jakarta II Jurusan Teknik Elektromedik misalnya pada setiap tahun ajaran baru menerima mahasiswa dan mahasiswi baru dengan jumlah 80 mahasiswa untuk dua kelas, disini dituntut suatu pekerjaan yang cepat dalam waktu yang sangat singkat yaitu mendata jumlah pendaftar, mempersiapkan seleksi calon mahasiswa melalui uji tulis dan uji kesehatan hingga mahasiswa dinyatakan sebagai mahasiswa baru pada institusi tersebut. Kemudian ditambah dengan jumlah mahasiswa lama yaitu tingkat satu dan tingkat dua yang jumlahnya kurang lebih 160 mahasiswa. Melihat keadaan tersebut tentunya jenis pekerjaan yang dihadapi selalu sama dan bersifat rutin dari tahun ke tahun seperti entry biodata mahasiswa baru, membuat KTM (Kartu Tanda Mahasiswa), Kartu Perpustakaan, Keterangan Domisili (bagi mahasiswa dari daerah), entry KRS (Kartu Rencana Studi), entry nilai UTS dan UAS, mencetak KHS
(Kartu Hasil Studi), dan mencetak Transkrip jika mahasiswa tersebut telah lulus. Hal tersebut diatas apabila dikerjakan secara manual membutuhkan waktu yang cukup lama dan tenaga yang cukup banyak, sedangkan pekerjaan tersebut harus segera di selesaikan dengan cepat.

Peranan pengolahan data dengan menggunakan komputer sangat mendukung, dimana data akan diolah menjadi informasi, dan informasi ini akan menjadi ilmu pengetahuan, dan ilmu pengetahuan ini yang akan menjadi modal dalam meningkatkan kinerja khususnya dalam melayani kebutuhan masyarakat. Meningkatnya kebutuhan informasi yang menuntut serba lebih cepat dan tepat ini merupakan suatu hal yang mendorong penanganan administrai dari tenaga manusia atau sistem manual cenderung dialihkan dengan menggunakan sistem komputer.

Sistem komputer dirancang untuk menangani permasalahan rutin yang dihadapi dan mampu mengolah data dalam jumlah yang sangat besar dalam waktu yang singkat serta mempunyai ketelitian yang tinggi. Sehingga akan memberikan kemudahan bagi pemakaianya dalam upaya menyajikan informasi dan layanan yang up to date.

Di lembaga pendidikan tujuan mendidik mahasiswa adalah untuk mengarahkan, menyiapkan, meningkatkan dan mengembangkan potensi Sumber Daya Manusia 
(SDM), agar memiliki pengetahuan, pemahaman dan ketrampilan sehingga mampu bersaing merebut peluang yang tumbuh dan berkembang di lingkungannya. Dengan demikian pendidikan tinggi bertugas untuk menyiapkan sumber daya manusia yang siap menghadapi perubahan sebagai akibat dari pesatnya kemajuan ilmu pengetahuan dan teknologi.

Dalam dasa warsa terakhir, pendidikan bukan hanya merupakan sektor penyedia pelayanan umum saja tetapi juga sebagai investasi produktif yang memicu pertumbuhan dalam berbagai bidang. Untuk itu diperlukan konsep-konsep, kebijakan, dan program-program pendidikan yang diharapkan dapat menghasilkan sumber daya manusia dengan karya-karya yang membanggakan.

Penyelenggaraan pendidikan harus didukung oleh sivitas akademika yang meliputi Sumber Daya Manusia seperti dosen, mahasiswa dan pegawai. Lembaga pendidikan dituntut untuk bisa menyelenggarakan pendidikan bermutu bagi para peserta didik.

Karyawan sebagai salah satu komponen atau unsur lembaga pendidikan yang diharapkan dapat memainkan peranan yang positif, memiliki kemampuan serta berusaha mengadakan perbaikan dan peningkatan kualitas pelayanan untuk memberikan kepuasan kepada konsumen dalam hal ini adalah mahasiswa. Usaha peningkatan produktivitas kerja karyawan diwujudkan melalui kegiatan efisiensi sumber-sumber yang dimiliki lembaga, baik efisiensi internal maupun eksternal.

Efisiensi internal dilakukan dengan mengoptimalisasikan penggunaan sarana dan prasarana yang dimiliki lembaga dengan caracara yang inovatif dan kreatif serta pelayanan kepada mahasiswa secara lebih efektif. Usaha peningkatan efisiensi eksternal dilakukan dengan mengembangkan, keahlian pegawai seperti diikutsertakan dalam program pendidikandan pelatihan, seminar, kursus ketrampilan, dan lain-lain.

Dalam usaha peningkatan pegawai juga dilakukan melalui program pendayagunaan dan peningkatan potensi yang dimiliki, antara lain; perbaikan iklim kerja, mengusahakan fasilitas kerja yang memadai dan menyesuaikan bidang tugas dan kemampuan karyawan yang ada serta menciptakan iklim yang mendukung keberhasilan proses pembelajaran.

Hal yang cukup berpengaruh dalam sistem pengelolaan pendidikan adalah pelayanan administrasi akademik yang terbakukan dan tidak mengalami perubahan yang berarti dari waktu ke waktu. Perkembangan Ilmu Pengetahuan dan Teknologi di dunia pendidikan merupakan tantangan yang harus dihadapi. Dalam peningkatan kualitas pelayanan administrasi akademik 
perlu dilakukan dengan cepat dan memuaskan kepada mahasiswa sehingga Institusi mempunyai reputasi baik. Upaya peningkatan kualitas pelayanan administrasi akademik tidak hanya dalam rangka menciptakan tenaga karyawan bermutu melainkan juga diharapkan melahirkan Sumber Daya Manusia yang mempunyai dedikasi dan profesional.

Dalam proses pembelajaran bukan hanya tergantung pada faktor dosen, mahasiswa, sarana dan prasarana yang memadai, tapi tidak kalah pentingnya adalah program pelayanan. Kualitas pelayanan merupakan masalah yang komplek dan mendasar, kualitas pelayanan perlu ditingkatkan agar dapat memenangkan persaingan.

Bagaimana pelayanan kepada mahasiswa ini bisa dilakukan oleh para dosen dan pegawai administrasi dengan sebaik baiknya. Upaya agar pegawai adiministrasi bisa menampilkan dirinya secara prima adalah dengan meningkatkan mutu pelayanan secara serius. Apabila hal tersebut tidak dapat dilakukan dengan baik maka akan menimbulkan suatu gejala yang disebut konsumerisme yaitu suatu kegiatan protes dari pihak konsumen yang mempunyai posisi lemah menghadapai produsen, karena konsumen merasa dirugikan oleh produsen terhadap produk yang tidak terjamin, kurang bermutu atau tidak sesuai dengan apa yang di informasikan.

Tidak dapat dipungkiri bahwa mutu dosen, tenaga administrasi adalah sumber daya yang sangat potensial bagi perguruan tinggi atau lembaga pendidikan, karena dosen dan tenaga administrasi dapat memberikan pelayanan dengan mutu tinggi kepada para mahasiswa, dan dosen merupakan agen marketing yang dapat menimbulkan daya tarik tersendiri bagi para mahasiswa. Para mahasiswa yang baru masuk pada suatu lembaga pendidikan akan sangat terkesan oleh dosen dan pelayanan administrasi yang dapat memberikan semangat dan harapan kepada para mahasiswa, yaitu dengan berbagai gayanya dalam memberikan kuliah serta model pelayanan administrasi oleh tenaga administrasi.

Untuk menghindari adanya gejala konsumerisme, maka perlu sekali perguruan tinggi atau lembaga pendidikan menempatkan tenaga administrasi dan dosen yang bermutu dalam jajarannya, sebab suatu jenis pelayanan yang baik akan menimbulkan image dan efek yang positif terhadap lembaga tersebut. Dan untuk membagun image yang baik terhadap suatu lembaga dalam rangka menarik minat sejumlah calon mahasiswa, maka perlunya perguruan tinggi mengembangkan berbagai upaya, salah satunya adalah meningkatkan mutu dosen, dan tenaga administrasi. 
Program peningkatan kualitas pelayanan haruslah dilakukan pada setiap perguruan tinggi atau lembaga pendidikan, hal ini dimaksudkan agar dengan peningkatan kualitas pelayanan kepada mahasiswa, dan proses pembelajaran yang dilakukan para dosen akan lebih baik sehingga akan menimbulkan image yang positif.

\section{METODE PENELITIAN}

Dalam dunia penelitian ilmiah dikenal suatu jenis metode yang lazim dipergunakan, salah satunya adalah metode deskriptif. Menurut Winarno Surakhmad "Metode adalah cara utama yang dipergunakan untuk mencapai tujuan, misalnya untuk menguji serangkaian hipotesis, dengan mempergunakan teknik serta alat-alat tertentu" (1980, h.131). Penelitian ini membahas tentang Hubungan Sistem Komputerisasi Dengan Kepuasan Mahasiswa di Politeknik Kesehatan Jakarta II Jurusan Teknik Elektromedik. Karena pemecahan masalah ini memerlukan data yang aktual atau sungguh terjadi pada saat ini, maka metode yang dipergunakan ialah metode deskriptif, penelitian deskriptif adalah Penelitian yang terbatas pada usaha pengungkapan suatu masalah dan keadaan sebagaimana adanya, sehingga hanya merupakan penyingkapan fakta, sedangkan tujuannya adalah untuk membuat pencandraan secara sistimatis, faktual, dan akurat mengenai fakta-fakta dan sifat-sifat populasi atau daerah tertentu

Populasi dalam penelitian ini adalah seluruh mahasiswa Politeknik Kesehatan Jakarta II Jurusan Teknik Elektromedik tahun akademik 20022003 sebanyak 100 mahasiswa, dan dari jumlah tersebut penulis menetapkan sebanyak 30 mahasiswa sebagai sampel penelitian. Populasi ini terbatas pada mahasiswa jurusan Teknik Elektromedik, dan memfokuskan pada sistem komputerisasi sebagai variabel yang berpengaruh terhadap kepuasan mahasiswa, sedangkan teknik yang digunakan di dalam pengambilan sampel ini adalah Simpel Random Sampling, karena pengambilan sampel dari semua anggota populasi dilakukan secara acak tanpa memperhatikan strata yang ada dalam anggota populasi itu. Oleh karena itu penulis menetapkan 30 mahasiswa untuk mengisi pernyataan yang ada dalam angket yang berhubungan dengan sistem komputerisasi dan pernyataan angket yang menyatakan kepuasan. Hasil keduanya akan penulis bandingkan untuk dianalisa apakah sistem komputerisasi mempengaruhi kepuasan mahasiswa di Politeknik Kesehatan Jakarta II jurusan Teknik Elektromedik.

\section{Pengumpulan Data}

Guna membantu memecahkan masalah dalam rangka 
penulisan skripsi ini, maka dalam pengumpulan data, penulis melakukan berbagai cara diantaranya adalah:

a. Studi Kepustakaan.

Melalui studi kepustakaan ini penulis mempelajari berbagai literatur dan bacaan-bacaan yang erat hubungannya dengan judul yang penulis susun, terutama teori yang berkaitan dengan komputerisasi dan pelayanan yang dapat memberikan kepuasan terhadap konsumen.

b. Studi Lapangan

Dengan metode studi lapangan penulis mengadakan penelitian untuk memperoleh data tentang bagaimana peran pimpinan terhadap pelaksanaan pelayanan dalam rangka memberikan kepuasan kepada mahasiswa. Adapun metode yang penulis lakukan adalah:

1) Observasi

Dalam pengumpulan data ini penulis mengamati, mencatat kegiatan rutin pimpinan dan unit pelayanan mahasiswa yang ada di Politeknik Kesehatan Jakarta II jurusan Teknik Elektromedik.

2) Angket

Dengan angket yang penulis sebarkan kepada mahasiswa, maka penulis dapat mengumpulkan data melalui pernyataan tertulis, mengenai aspek-aspek yang akan di ukur yaitu mengenai sistem komputerisasi yang ada di Politeknik Kesehatan Jakarta II jurusan Teknik Elektromedik dan kepuasan mahasiswa. Angket sebagai alat pengumpul data untuk variabel $\mathrm{X}$ dan $\mathrm{Y}$ memiliki 20 item pernyataan. Setiap item yang ada dalam angket memiliki rentang jawaban dengan bobot skor antara 1 sampai 5. menurut skala likert pembobotan nilai kategori jawaban dapat dilihat pada tebel berikut ini:

\section{Skor Angket}

TTabel. Pembobotan Skor Angket Penelitian

\begin{tabular}{|c|c|}
\hline Alternatif Pilihan & Bobot Skor \\
\hline Sangat Setuju (SS) & 5 \\
\hline Setuju (S) & 4 \\
\hline Cukup (C) & 3 \\
\hline Tidak Setuju (TS) & 2 \\
\hline Sangat Tidak Setuju (STS) & 1 \\
\hline
\end{tabular}

\section{Kisi-kisi Instrumen Penelitian}

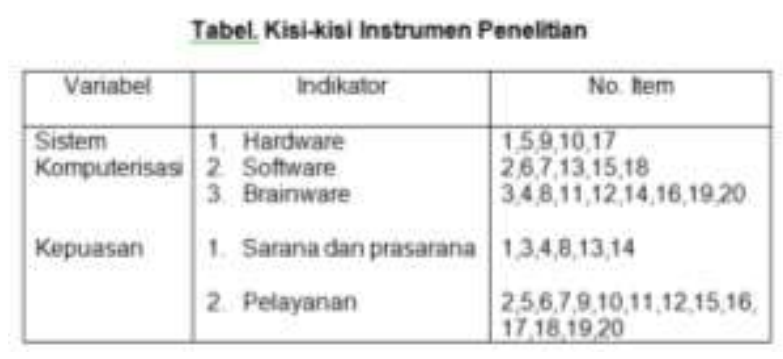

Untuk menentukan kevaliditasan dari angket, maka dapat digunakan dua pengujian melalui Uji Validitas dan Uji Reliabilitas (ketetapan). 


\section{Uji Validitas Instrumen}

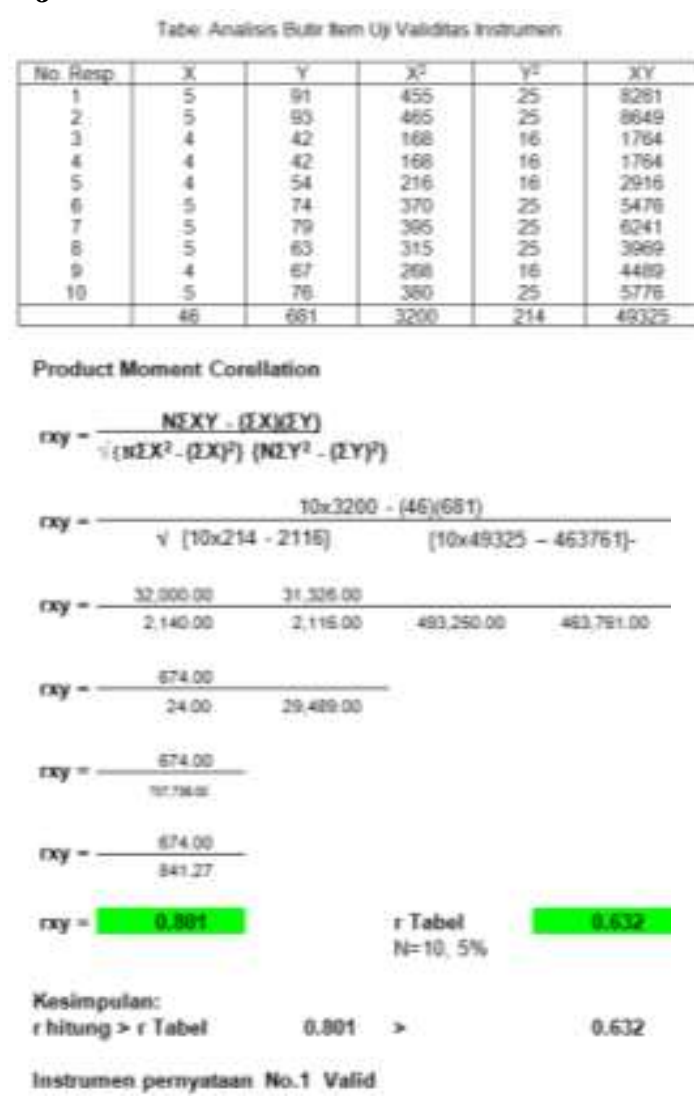

Setelah

dilakukan

perhitungan terhadap skor yang diperoleh dalam uji coba instrumen terhadap 10 orang mahasiswa, maka diketahui nilai variable Sistem Komputerisasi (X) yaitu diperoleh $\mathrm{r}_{\text {hitung }}$ untuk butir pernyataan No.1 sebesar 0,801 , sedang $r_{\text {tabel }}$ dengan $\mathrm{N}$ $=10$ dan taraf signifikansinya $=0,05$ adalah 0,632 . Ini berarti $r_{\text {hitung }}$ lebih besar dari $r_{\text {tabel }}\left(r_{\text {hitung }}>r_{\text {tabel }}\right)$, sehingga dapat diaambil suatu kesimpulan bahwa item No. 1 valid. Sedangkan perhitungan butir instrumen yang lainnya (nomor $2 \mathrm{~s} / \mathrm{d}$ 30) yang digunakan untuk menjaring data Sistem Komputerisasi juga valid.

\section{Uji Reliabilitas}

Untuk menguji angket diatas maka digunakan uji reliabilitas. Instrumen yang reliable akan menghasilkan data yang dapat dipercaya. Uji reliabilitas dilakukan dengan menggunakan metode yang lebih efisien yaitu Split half method (metode belah dua), yaitu metode mengelompokkan hasil dari suatu tes dibagi atau dibelah menjadi dua bagian yaitu:

a. Bagian pertama berupa hasil atau skor yang berasal dari item-item bernomor ganjil.

b. Bagian kedua berupa hasil atau skor dari item-item yang bernomor genap.

Data yang diperoleh dihitung dengan rumus korelasi product moment , perhitungan dilanjutkan dengan rumus Spearman-Brown karena perhitungan dengan rumus Pearson baru mengukur reliabilitas separuh tes. Rumus yang digunakan untuk reliabilitas separuh tes yaitu:

$$
r_{1 / 21 / 2}=\frac{n \sum X Y-(\Sigma X)(\Sigma Y)}{V\left\{N \Sigma X^{2}-(\Sigma X)^{2}\left(n \Sigma Y^{2}\right)-\left(\Sigma Y^{2}\right)\right\}}
$$

Sedangkan rumus Spearmen Brown adalah sebagai berikut:

$$
\begin{array}{r}
r 11=\frac{2 \times r_{\mathrm{gg}} \text { atau } r_{\mathrm{bb}}}{1+r_{\mathrm{gg}} \text { atau } r_{\mathrm{bb}}} \\
\text { Berdasarkan perhitungan } \\
\text { terhadap hasil uji coba variable }
\end{array}
$$


Sistem Komputerisasi (X) diperoleh $\mathrm{r}_{\text {hitung }}$ sebesar 1,99 pada $\mathrm{N}=10$ dengan taraf signifikansi $=0,05$ adalah 0,361, maka dapat disimpulkan bahwa angket yang digunakan untuk menjaring data variable $\mathrm{X}$ adalah reliable. Kemudian dari $r_{\text {hitung }}$ yang diperoleh dari perhitungan tersebut di interpretasikan kedalam dalam interpretasi " $\mathrm{r}$ " sebagai berikut:

\begin{tabular}{|c|c|}
\hline Besarmya nilai ? & nteqpentasi \\
\hline $0,01-1,00$ & Korelasi sangaf tingo \\
\hline $0.71-0.90$ & Konelasi tingoi \\
\hline $0,41-0,70$ & Koreias culoup \\
\hline $0.21-0.40$ & Korelasi rendah \\
\hline Negatit -020 & Korulass sangat rendan \\
\hline
\end{tabular}

\section{Pengujian Hipotesis}

\section{Analisa Data}

Analisa data merupakan usaha konkrit atau nyata untuk membuat data bisa berbicara atau di informasikan, dan untuk menganalisa data yang diperoleh dari penyebaran angket kepada para mahasiswa dipergunakan rumus statistik sebagai berikut:

a. Product moment

b. Uji t student

c. Koefisien determinasi (KD)

Sebelum melakukan penghitungan terhadap jawaban angket yang telah terkumpul, dilakukan pemilahan antara jawaban angket yang berkaitan dengan sistem komputerisasi dan kepuasan, kemudian membuat tabel-tabel sesuai dengan kebutuhan untuk memasukkan nilai yang tertera dalam angket dan selanjutnya untuk melakukan analisa data, proses penghitungannya penulis mempergunakan alat bantu komputer dengan software Microsoft Excel.

TABEL: JAWABAN RESPONDEN TENTANG SISTEM KOMPUTERISASI $(X)$
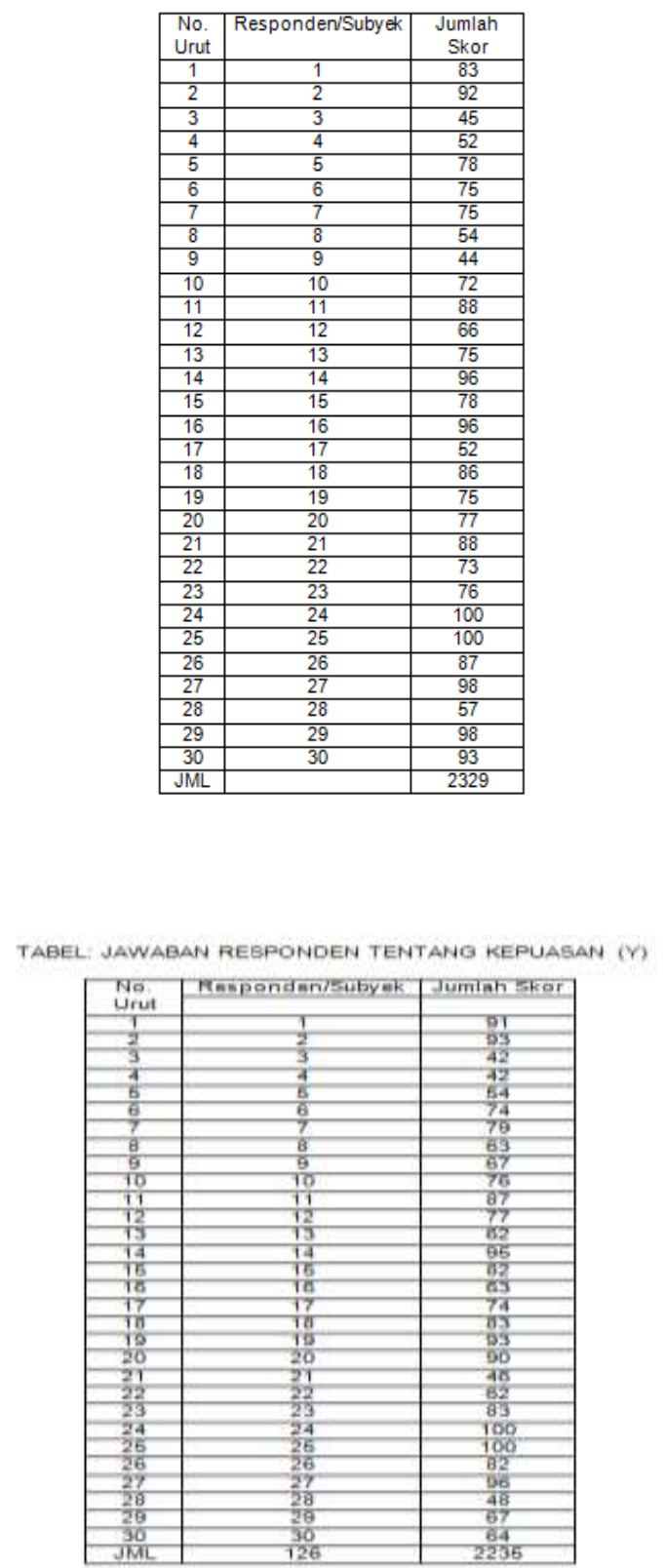


\section{Pengujian}

\section{Hipotesis}

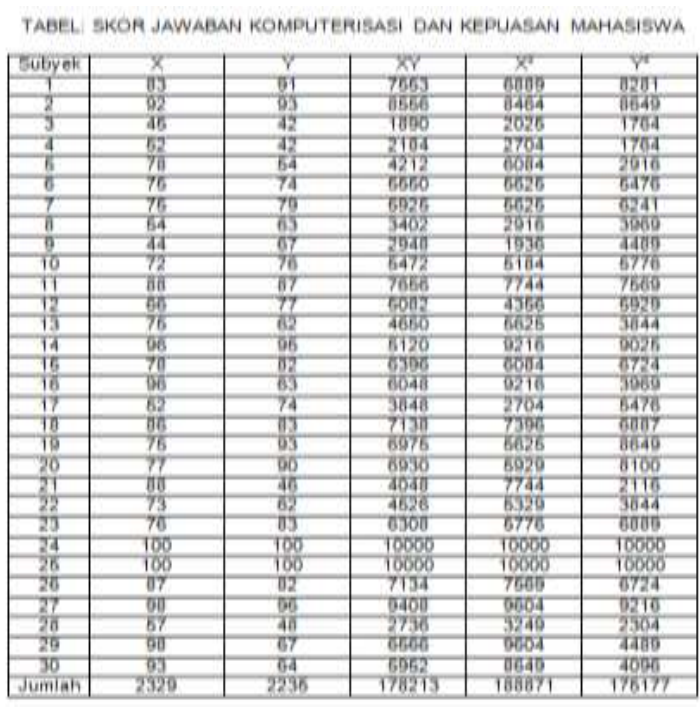

\section{Koefisien Korelasi}

Berdasarkan Tabel diatas untuk melakukan pengujian hipotesis mengenai hubungan antara variabel $\mathrm{X}$ dan $\mathrm{Y}$ dipergunakan rumus korelasi Product Moment dari Pearson sebagai berikut:

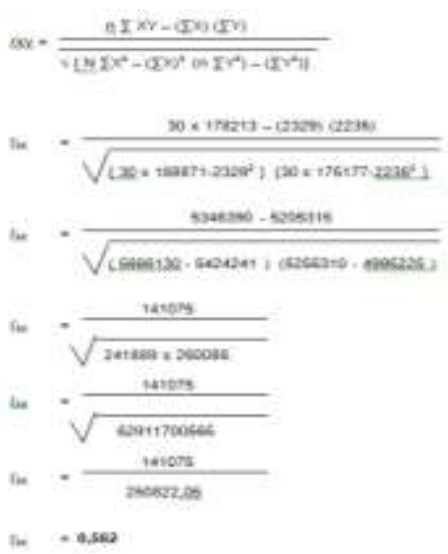

Berdasarkan perhitungan diatas, didapatkan koefisien korelasi sebesar 0,562 nilai perhitungan tersebut dikonsultasikan dengan nilai $r$ di tabel product moment untuk $\mathrm{N}=30$ pada taraf signifikansi 0,05 adalah sebesar 0,361 dengan

Kriteria Pengujian Hipotesis :

Tolak Ho jika $r_{\text {hitung }}>r_{\text {tabel }}$

Terima Ho jika $r_{\text {hitung }}<r_{\text {tabel }}$

Berdasarkan hasil perhitungan dan nilai korelasi diatas, $r_{\text {hitung }}>r_{\text {tabel }}$, atau 0,562 >0,361, maka dapat disimpulkan Ho ditolak. Hasil perhitungan menyimpulkan bahwa terdapat hubungan antara sistem komputerisasi dengan kepuasan mahasiswa Politeknik Kesehatan Jakarta II Jurusan Teknik Elektromedik.

\section{Perhitungan Taraf Signifikansi}

Kemudian untuk melihat nilai signifikansi atau nilai keberartian dari korelasi digunakan rumus Uji-t student

$$
\begin{aligned}
\mathrm{t} & =\frac{r \sqrt{n-2}}{\sqrt{1-r^{2}}} \\
& =\frac{0,562 \sqrt{30-2}}{\sqrt{1-0,562^{2}}} \\
& =\frac{2,98}{0,83} \\
& =3,60
\end{aligned}
$$

Berdasarkan hasil analisis data di atas, dapat diketahui bahwa $t_{\text {hitung }}$ lebih besar dari $t_{\text {tabel }}$ (nilai kritisnya) pada taraf signifikansi 0,05 ; (df) $\mathrm{N}-2$ $=30-2=28$ adalah sebesar 1,70 . 
Dengan demikian dapat dikatakan bahwa : $t_{\text {hitung }}>\mathrm{t}_{\text {tabel }}$ atau 3,60> 1,70 maka Ho ditolak, sehingga dapat disimpulkan bahwa korelasi signifikan.

\section{Perhitungan Koefisien \\ Determinasi (KD)}

Untuk mengetahui besarnya derajat hubungan antara varibel $\mathrm{X}$ dengan variabel Y maka dilakukan perhitungan koefisien determinasinya. Perhitungan Koefisien Determinasi dihitung dengan menggunakan rumus :

$$
\begin{aligned}
\mathrm{KD} & =r^{2} \times 100 \% \\
& =0,562^{2} \times 100 \% \\
& =315.844 \times 100 \% \\
& =31,64 \%
\end{aligned}
$$

Dengan demikian, dapat disimpulkan bahwa variabel (X) sistem komputerisasi memberikan kontribusi atau sumbangan yang cukup yaitu $31,64 \%$ terhadap variabel (Y) kepuasan mahasiswa.

\section{Pembahasan}

Berdasarkan hasil uji statistik secara keseluruhan dapat dikemukakan beberapa hal antara lain:

1. Antara variabel sistem komputerisasi dengan kepuasan mahasiswa terdapat hubungan yang cukup berarti.

2. Antara variabel sistem komputerisasi dengan kepuasan mahasiswa memiliki korelasi yang signifikan.

3. Sistem komputerisasi yang diterapkan pada institusi dapat memberikan kontribusi yang mengakibatkan kepuasan kepada mahasiswa sebesar $31,64 \%$.

Dengan ini terlihat bahwa ada hubungan yang cukup signifikan antara sistem komputerisasi dengan kepuasan mahasiswa di Politeknik Kesehatan Jakarta II jurusan Teknik Elektromedik.

\section{KESIMPULAN}

Dari hasil analisa data berdasarkan pengolahan data penelitian dapat disimpulkan hal-hal seperti di bawah ini:

1. Dari perhitungan mengenai bentuk hubungan (korelasi) antara sistem komputerisasi dan kepuasan mahasiswa di dapat nilai $r_{\text {hitung }}$ sebesar 0,562 , dan $\mathrm{r}_{\text {tabel }}$ sebesar 0,361 yang berarti bahwa sistem komputerisasi di Politeknik Kesehatan Jakarta II Jurusan Teknik Elektromedik dan kepuasan mahasiswa terdapat hubungan (korelasi) yang positif.

2. Berdasarkan hasil perhitungan product moment kemudian dilakukan uji signifikansi, dengan menggunakan uji t yaitu mengalikan nilai $r$ dengan akar $\mathrm{N}-2$, kemudian dibagi dengan akar 1-r kuadrat, dan ternyata didapat $t_{\text {hitung }}$ lebih besar dari 
$\mathrm{t}_{\text {tabel }}(3,60>1,70)$ pada tingkat kepercayaan 0,95.

3. Kontribusi yang diberikan oleh variabel

$\mathrm{X}$

(Sistem Komputerisasi) terhadap variabel Y (Kepuasan Mahasiswa) sebesar 31,64\%, nilai ini dihitung dengan mengkuadratkan nilai $r$ dikalikan $100 \%$ menggunakan rumus Koefisien Determinasi (KD).

\section{REFERENSI}

Buku Diktat Kuliah (2003). Pengetahuan dan Praktik Komputer, Jakarta.

Hamalik, Oemar, (1989). Komputerisasi Pendidikan Nasional, Bandung CV. Mandar Maju.

Irawan Handi, (2002). 10 Prinsip Kepuasan Pelanggan, Jakarta: PT. Gramedia.

Kotler Philip, (1995). Manajemen Pemasaran, Jakarta: Salemba Empat.

Kusumo Tjipto, Pengantar Sistem Informasi Manajemen, PT Elex Media Komputindo. Jakarta: Gramedia.

Longkutory, J John. (1988). Pengenalan Komputer, Bandung: Sumber Widya. Noersasongko Edi, (1985). Mengenal Dunia Komputer, Jakarta : Pendidikan Komputer Santa Lusia.

S. Nasution, Metode Research (Penelitian Ilmiah), Bumi Aksara, Jakarta, 1996.
Simangungsong, Bonar, (1991). Sistem Informasi Manajemen, Jakarta : PT, Paherindo,.

Sudjana, (1986). Metode Statistik, Bandung: Tarsito.

Siegel Sidney, (1985). Statistik Nonparametrik Untuk Ilmu Sosial, Jakarta : PT. Gramedia.

Syani Abdul, (1985). Pengantar Metode Statistik Nonparametrik, Jakarta : Pustaka Jaya.

Wijanarko, Fredy, (1992). Design Sistem \& Teknik Pemrograman, Jakarta : Dinastindo. 